\title{
Lifestyle Pattern And Hedonic Motives In Family Finances (Studies On Career Women And Married Women In Medan)
}

\author{
Onan M Siregar, Hosianna Ayu Sihombing, Ainun Mardhiyah \\ Study Program of Business Administration, \\ University of Sumatera Utara, Medan, Indonesia
}

\begin{abstract}
This research was conducted to discover that the women in order to determine the pattern lifestyle and hedonist motives could adversely affect the financial and lifestyle patterns like what they are able to bring a good impact on their financial condition so that the pattern of life and the motives of hedonism can be balanced with the family finances. The study also wants to make people aware of the importance of financial management in order to be well planned life patterns in the future and avoid the lifestyle patterns that does not match the capabilities / revenues from the financial side. This study uses a qualitative approach to the analysis descriptive. Primary data were collected by asking the respondents to answer questions and statements about their perceptions. The results of this study found that the pattern of lifestyle and hedonic shopping motivation in women to work and settle down in Medan City, generally have a lifestyle patterns that are still good. It is indicated in the pattern of family financial arrangements, revenue and expenditure, the selection of the priority needs and desires in fulfilling lifestyle and able to withstand their hedonic characters categorized as a woman in normal condition. Respondents also have more income than spending. It is concluded that the pattern of lifestyle and Hedonic Shopping Motives can be balanced with family finances.
\end{abstract}

Keyword: Lifestyle Patterns; Hedonism Motives; Family Finance

\section{INTRODUCTION}

Money is a medium of exchange that is commonly used in the transaction. In practice, it often becomes the main factor of causing the problem. Financial problems often caused disputes between individuals, siblings, parents and couples are eventually cause discord and divorce. Disputes concerning finances could happen in the current financial conditions in the current overflow or lack of money. In addition to financial problems, can result in mistrust, putting personal interests rather than the family, causing dishonesty, and even divorce. Therefore, the recently frequently found someone's motivation in doing acts of criminality by reason of financial problems, which is to meet the needs and desires for himself.

Family financial problems are often due to individual's lack of understanding of financial literacy and bad financial arrangements. It is indicated from lifestyle patterns is not balanced with income and emerging of hedonic character to the consumers who tend to buy without prioritizing shopping priorities according to the needs. For everyone, shopping would be a fun activity, especially for women. In addition to meeting the needs, shopping activities can be fun for yourself to relieve boredom. Hedonic shopping motives will be created by shopping and sightseeing or window shopping to choose goods according to passion. When shopping, someone will have a positive emotion to buy the product without prior planning in the form of notes shopping list. Hedonic shopping motives (hedonic shopping motivation) is the behavior of individuals who carry out shopping activities excessively to meet its own satisfaction. The reason why a person has the hedonic characters among which many needs that cannot be fulfilled before, then after the requirements are met, new needs arise and sometimes the need is higher than ever. Hedonic shopping motives will be created with the passion of someone who is easy to shop affected by lifestyle affected by the social environment and 
latest models (trend) to meet the needs and desires.

Today's modern life is taught to take action consumptively. There are rare cases of a person's lifestyle in meeting the needs and desires that lead to the hedonic characters end up in tangled financial problems. It is caused especially by getting easier for the people to have credit cards. Women are the most who do transactions with a credit card. One proof of that is the $69 \%$ increase in transactions by credit card holders UOB Lady's Platinum and Lady's Card between 2013 and 2014 (keuangan. Kontan December 29, 2014 edition). Excessive use of credit cards will incur interest that could trap them into this quagmire of debt (Kontan 18 edition.24 April 2011).

Generally, family finances on hold by the wife's role in its management. In the development and reformation era, absolutely needs a virtuous and the ideal woman, the woman who can run the dual role of being the wife and has got career that will manage two sources of income. Not infrequently found that women who perform the dual role, and be highlighted spotlight in this study were women in Medan City. Medan is the third largest metropolitan city in Indonesia after Jakarta and Surabaya. Therefore, any shopping center is easy to reach. Medan is also the city with the largest population in Sumatra and fourth in Indonesia, and women still a greater amount of population than men (wikipedia.org).

Therefore, based on this background, this study aims to determine the pattern of life (lifestyle) and hedonic shopping motives (hedonic shopping motivation) that could adversely affect the family finances, and lifestyle patterns like what they are able to bring a good impact to the financial condition so that Lifestyle and hedonic shopping motives can balance the family finances. The study also wants to make people aware of the importance of financial management in order to be well planned life patterns for life in the future and avoid lifestyle patterns that does not match the capabilities / revenues from the financial side.

\section{RESEARCH METHODS}

This research uses descriptive method with qualitative analysis. The location of this research is on the 5 districts located in Medan City. The choice of location based on the characteristic of the people in Medan city especially the women who have hedonic characters.

Data collection techniques used in this research is the literature study. Interviews technique and data analysis used in this research is descriptive analysis that is to describe the results of the research that has been obtained from interviews with the informants. The Population in this study was women and has jobs/career. Informants in this study were obtained randomly.

The stage of collecting data in this study is according to Miles and Huberman, there are three techniques of qualitative data analysis: data reduction, data presentation and conclusion. This process takes place continuously during the study, even before the data is actually collected.

\section{1) Reduction of Data}

Data reduction is one of the techniques of qualitative data analysis. Data reduction is a form of analysis which sharpens, classify, direct, dispose of unnecessary and organizing data such that the final conclusions can be made. Reduction of data need not be defined as the quantification of data.

\section{2) Presentation of Data}

Presentation of data is one of the qualitative data analysis techniques. Presentation of data is an activity when a set of structured information, thus giving the possibility of a conclusion. Form of presentation of qualitative data in the form of narrative text (in the form of field notes), matrices, graphs, and charts network.

\section{3) Making Conclusion}

Conclusion is one of the techniques of qualitative data analysis. Making conclusion is the result of analysis that can be used to take action. 


\section{RESULT AND DISCUSSION}

\section{A. Data Respondents}

The results showed that the respondents in this research, the majority as much as $48 \%$ have the number of children of $1-2$ children, $35 \%$ of respondents have a number of 3- 5 children, the number of children more than 5 by $7 \%$ and $10 \%$ of respondents have not been blessed with children. For the age category of respondents, aged of 24-34 years old by $30 \%$, the majority of respondents ages $35-45$ years old were $58 \%$, and more than 45 years old as much as $12 \%$. For the category of last education of respondents, elementary and secondary schools as much as $10 \%$, High School and D1 as much as $15 \%$, the majority of respondents have the latest education of D3 and S1 as much as $70 \%$, and for the respondents whose last education S2 and S3 are 5\%.

\section{B. Lifestyle and Hedonic Shopping Motives in Family Finance}

\section{Earnings per Month}

Where a majority of respondents in 53\% with a range of income as much as Rp.1.000.001 Rp.5,000,000 per month, 33\% of respondents earning> Rp.5.000.000 and 14\% respondents income <Rp.1.000.000 per month. There are 4 types of the objectives of respondents work, they are:

- $45 \%$ of respondents work to supplement the family income (extra income from the husband)

- $40 \%$ of respondents work because the demands of family

- $10 \%$ of respondents work just to fill spare time.

- $5 \%$ of the respondents work for the work carried out is a hobby

\section{Spending per Month}

The average spending per month of $50 \%$ of respondents with an average expenditure of Rp.1.000.001 - 5,000,000 per month, $40 \%$ of respondents spending an average of > Rp.5.000.000 and spending as much as $10 \%$ of respondents Average < Rp.1.000.000 per month. There are three types of routine expenditure of respondents in this study, namely: expenditure on daily needs that reflect the fulfilling basic needs of respondents, spending on entertainment / family holidays and self-satisfaction to meet the secondary needs of respondents, spending on credit card repayments and repayments of other, spending for savings, and spending of social funds.

- $40 \%$ of respondents spending to meeting the basic needs include: Monthly Expenditure (basic needs) Monthly Recurring Payment such as electricity, water, household assistant salary, Children's Education (School fee, course fee)

- $25 \%$ of respondents spending on entertainment / holiday family and herself as a secondary needs fulfillment include: body treatment / beauty clinic, Entertainment (such as a movie or having meals at the Mall with family)

- $20 \%$ of total expenditure of respondent to pay credit card (purchased product as: household furniture, mobile phone, etc.) other installment (like vehicles, house mortgage, etc.)

- $10 \%$ of respondents spending was also allocated to savings, investment, and insurance

- $5 \%$ of respondents spending for social expenditure (such as zakat, infaq/charity, etc.)

Characteristics of respondents according to the pattern of lifestyle and hedonic motives are shown in the following analysis:

1. In this study obtained information that the most fun activities performed by the following:

The majority of respondents as many as $45 \%$ do leisure activities / Tourism (such as watching movies, eating in a mall or shopping center, recreation inside and outside the city). This is also strengthened by the question of how often the respondents to visit the shopping center, $80 \%$ of respondents stated often or more than seven times a month visit the Mall or Shopping Centre while the remaining $20 \%$ is not too often or range of 2 to 6 times a month. Other activities such as self-care (in the salon or beauty clinic), social interaction (such as visiting a relative's house, or get together with friends / community), Doing hobby (such as sports activities, etc.) each to the role as many as $10 \%$, and last $25 \%$ going shopping is considered unpleasant by the respondent. 
2. Continuing from the previous analysis that the majority of respondents frequently visited shopping centers and shopping is considered unpleasant things can be analyzed respondents' motivation in shopping as follows:

The majority of respondents $50 \%$ say that it is indeed in need of such products, as many as $30 \%$ of respondents said that the quality and brand of the product and the remaining $20 \%$ said because sudden shopping (so as to buy an attractive appearance of the product.)

3. Products purchased (beside basic needs) or that require installment (credits) to buy as many as $75 \%$ said the vehicles are goods that are required to have. It is based on reasons for the respondents to have vehicles as many as 50\% for easy mobility and support of respondents in work. And the remaining 25\% respectively said that had it for self-actualization vehicle (style) and as Luxury (which will follow the latest trend of the type of vehicle). While the remaining $15 \%$ say buy furniture households also be done with the mortgage payments, and last as much as $10 \%$ for investment (such as buying a home or a mortgage

4. Lack of awareness of respondents on financial management with the percentage of respondents who have arranged personal financial statements / simple bookkeeping as many as 35\% (usually new couples) smaller than the respondents who haven't prepared personal financial statements / simple bookkeeping by $65 \%$ respondents have not or do not do. It is because of the family's two sources of funding in the family income of respondents that considered able to sustain unexpected costs and does not require a personal financial statement.

\section{CONCLUSION}

From the results of this study found that the pattern of lifestyle and hedonic shopping motivation (Hedonic Shopping Motives) in women to work and settle down in Medan City, generally have a lifestyle patterns that are still good. It is indicated in the pattern of family financial arrangements, revenue and expenditure, the selection of the priority needs and desires in fulfilling lifestyle and able to withstand their hedonic characters categorized as a woman in normal condition. Respondents also have more income than spending. It is concluded that the pattern of lifestyle and Hedonic Shopping Motives can be balanced with family finances. But it is unfortunate that the majority of respondents considers it and has not done the preparation of personal financial statements / simple bookkeeping. The reason the respondents because, the two sources of income funds so, can sustain the family finances and supposed that only new families (families who had recently just married) who usually do the arrangements of family financial statements due to they have not yet stabilized in family finance. Even so awareness of the respondents would be insurance, investment and savings are good enough. And in the habit of saving, respondents have already done investment routinely every month. It is indicated that respondents in this research have sufficient awareness both in perform a routine save and realized the importance of saving allocate it to the expenditure items into one allowance money that should routinely be done.

\section{SUGGESTION}

This research has not been able be generalized because the research was only done to 5 districts in Medan City, the districts are: Medan Baru, Medan Petisah, Medan Selayang, Medan Kota and Medan Maimun. Therefore, it is considered for future research is developed by involving 21 districts in Medan City that have not been mentioned that this study can be generalized.

\section{REFERENCES}

Anita, R. (2009). Total Phenol Content Noni Extract.University of Indonesia.

Almawadi, I. (2014, Dec). Penggunaan Kartu Kredit Oleh Wanita Naik Pesat. Retrieved 2016 from http://keuangan.kontan.co.id/.

Arnold, M. J., \& Reynolds, K. E., (2003, Feb).Hedonic Shopping Motivations.Journal of Retailing, 79,77-95.

Arnold, M.J., \& Reynolds, E.K. (2003).Hedonic Motivations.Journal of Retailing, 79, 77-79.

Gültekin, B., \& Özer, L. (2012).The Influence of Hedonic Motives and Browsing On Impulse 
Buying.Journal of Economics and Behavioral Studies.Vol. 4. No. 3 March: pp. 180-189. (ISSN: 2220-6140).

Kotler, P. (2000). Marketing Manaagement. Jakarta: PT. Prenhallindo.

Masassya, M. (2006).How to Manage Personal Finance. Jakarta: PT. Elex Media Komputindo

Miles, M. B., \& Huberman, A. M. (1992).Qualitative Data Analysis. Jakarta: University of Indonesia Press.

Overby, J. W., \& Lee. E. J. (2006). The Effects Of Utilitarian And Online Shopping Hedonic Value On Consumer Preference And Intentions. J Business Research, 59, 11601166.

Ramadan. (2008). How healthy is your life. Jogjakarta: Publishers Think.

Senduk, S. (2004). Managing Family Finance. Jakarta: Gramedia.

Sumarwan, U. (2003). Consumer Behavior. Jakarta: Publisher Ghalia Indonesia.

Utami, C. W. (2010). Retail Management. Jakarta: Four Salemba. 